\title{
Updating landslide inventory maps using high resolution digital orthophotos and Digital Surface and Elevation modeling: the case study of Brusque city, Santa Catarina State, Brazil
}

\author{
L. S. Osako ${ }^{1, *}$ \\ ${ }^{1}$ Department of Geology, Federal University of Santa Catarina, Brazil - liliana.osako@ufsc.br
}

KEY WORDS: landslide, inventory, remote sensing, digital orthophotography, DSM, DEM

\begin{abstract}
:
This study reports the updating of the landslide inventory map of Brusque city, State of Santa Catarina, Southern Brazil. Twenty-six digital orthophotos acquired in 2010 with a ground resolution of 0.4 meters were analyzed together with shaded relief images obtained by Digital Surface and Digital Elevation modelling with spatial resolution of 1 meter. These remote sensing products were treated, analyzed and visualized in a Geographic Information System - GIS environment. The landslide inventory included a total of 500 landslides, corresponding to a mean density of 1.76 landslides per $\mathrm{km}^{2}$. The total area of landslide occurrences is $0.81 \mathrm{~km}^{2}$, which corresponds to $0.29 \%$ of the study area. $0.22 \mathrm{~km}^{2}$ of the total area landslides occur inside the urban perimeter and $0.59 \mathrm{~km}^{2}$ outside Brusque. The geological context and the occurrence of landslides were analyzed together: 277 landslides affect altered metamorphic rocks, 179 landslides granite, and 44 landslides unconsolidated sediments. The updated landslide inventory map showed that $80 \%$ of mapped landslides occur in areas of high and moderate susceptibility.
\end{abstract}

\section{INTRODUCTION}

Natural disasters are consequence of several phenomena, such as floods, landslides, earthquakes, tornados, hurricanes, drought, among others. In Brazil, natural disasters associated with movements of materials such as soils, rock, and vegetation that cover slope surfaces are common. These mass movements can be triggered by natural causes (climatic conditions, geological weathering and erosion) and by human-related activities (disorderly occupation of slopes, deforestation). The development of new methodologies to recognize and identify landslide scars has been encouraged by researchers of the scientific community, once maps that represent mass movements in area cover only $1 \%$ of the emerged land (Guzzetti et al., 2012; Reichenbach et al., 2018). Landslide inventory maps have been updated using remote sensing imagery, because of the low-cost coverage of wide areas and the advantage of multi-temporal landscape pattern analysis.

The study area is located in the Itajaí-Açú river watershed in Brusque city, State of Santa Catarina, Southern Brazil (Figure 1). It is totalizes $283.3 \mathrm{~km}^{2}$ and includes Neoproterozoic low to medium-grade metasedimentary rocks intruded by granitoids, and Recent alluvial deposits (CPRM, 2003; Basei et al., 2011). This region underwent intense and prolonged rainfall, which caused more than 3,000 rainfall-induced landslides in November 2008. The landslide inventory available for the region contains only point data of the landslide occurrences (IPT, 2015).

The aim of this study is to update the Brusque city landslide inventory map and to provide information regarding quantity, area and perimeter of the landslides using high spatial resolution orthorectified digital aerial photos and Digital Elevation and Surface modeling (DEM and DSM) available for the region. Thus, this study presents a methodology to update the landslide inventory map using innovative techniques to analyze changes in the surface morphology observed in the DEM and DSM (Guzzetti et al., 2012; Mondini et al., 2014).

\footnotetext{
* Corresponding author
}

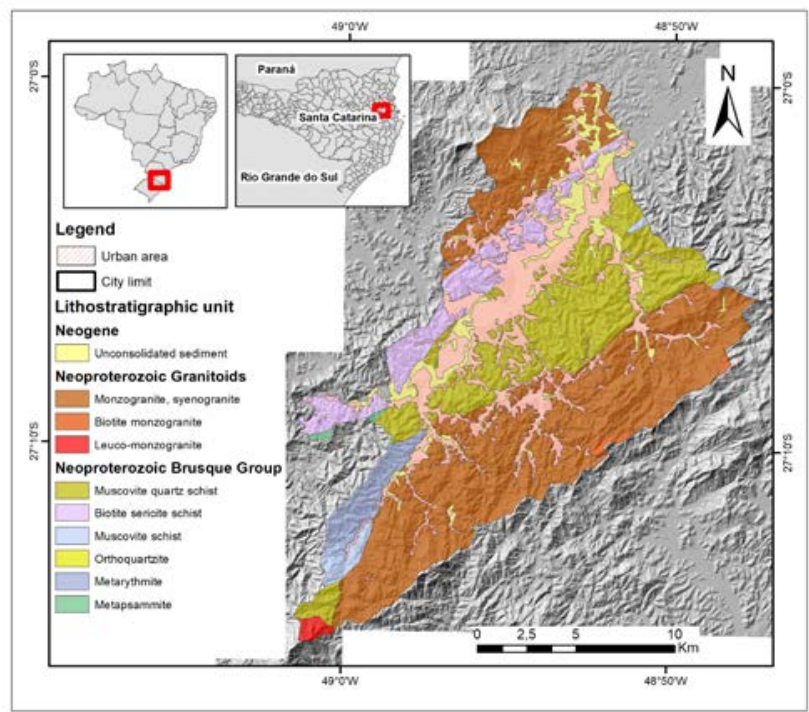

Figure 1. Schematic geologic map superimposed on a Digital Elevation Model of the Brusque City, Santa Catarina State, Brazil (Modified after Basei et al., 2011).

\section{THE LANDSLIDE INVENTORY MAP}

The landslide inventory map mainly provides information about the location of gravitational mass movement in a certain area. Additional information, such as the date and type of landslides, can also be part of the landslide inventory map. According to Guzzetti et al. (2012), three assumptions must be considered when preparing a landslide inventory: a) landslides leave discernible traces or signs in the landscape. For example, "landslide scars" can be recognized, classified and mapped in the field, from aerial photographs, satellite images and digital models of surface forms (surface topography). Such signs are detected by a) changes in the shape, position or appearance of the topographic feature; b) the landslide morphological signature, which depends on the mass movement type, for example, falls, topples, slides, flows, spread or combination of 
two or more types of movement (Varnes, 1978; Bordoni et al., 2020); and c) by certain phenomena, once gravitational mass movement does not occur by chance, mainly because slope stability is intrinsically related to physical processes and the laws of mechanics.

Landslide inventory maps are classified by the scale and the type of mapping (Guzzetti et al., 2000; Guzzetti et al., 2012). Small-scale $(<1: 200,000)$ landslide inventory maps show the locations of the landslides compiled from data obtained in the literature. Medium-scale landslide inventory maps (1:25,000 to $1: 200,000)$ are prepared from the systematic interpretation of aerial photographs and the integration of historical records. Large-scale landslide inventory maps $(>1: 25,000)$ are prepared by interpreting aerial photographs (scale greater than 1:20,000), high-resolution satellite images or digital terrain models, with the aid of field data. On the basis of the type of mapping, landslide inventory maps can be classified as geomorphological, event, multi-temporal or historical (Guzzetti et al., 2012; Reichenbach et al., 2018). The geomorphological inventory records landslides by physical features of the landscape. The event inventory shows landslide occurrences associated with triggering events, such as rainfall, typhoon, snowmelt or earthquake. There are "fresh" event inventory when mapping takes place shortly after the landslide event (Malamud et al., 2004). The multi-temporal inventory records landslide occurrences in different time periods in a same geographic area. The historical inventory shows the 'age' of the landslide in relative terms, such as recent, old or very old.

Landslide mapping methods can be divided into conventional and recent techniques. Six mapping techniques are well known (Guzzetti et al., 2012; Reichenbach et al., 2018; Bordoni et al. 2020): 1) visual interpretation of aerial photographs, 2) interpretation of satellite imagery, 3) field mapping, 4) interpretation of high resolution digital elevation models, 5) automatic or semi-automatic mapping using remote sensing imagery, and 6) collection of historical documents. A landslide inventory map can be prepared using multiple mapping techniques. The selection of the technique will depend mainly on the scope of the research, scale and resolution of the remote sensing imagery, and type of mapping of the landslides.

\section{MATERIAL AND METHOD}

\subsection{Data characteristics}

The identification of landslide scars was carried out using 26 orthorectified digital aerial photos at the 1:10,000 scale, acquired in 2010 by an airborne photogrammetric survey funded by the State of Santa Catarina government. The spatial resolution of the digital orthophotos is 0.4 meters. Digital Elevation (DEM) and Digital Surface (DSM) models were derived from the digital orthophotos with at $0.4 \mathrm{~m}$ resolution resampled to $1 \mathrm{~m}$ (SDS, 2010). The remote sensor imageries and other cartographic bases treated, analyzed and visualized in a Geographic Information System - GIS environment using software QGIS.

\subsection{Visual analysis and interpretation}

The recent landslide mapping method was applied and included visual interpretation of digital orthophotos and DEM and DSM shaded relief images, in order to identify landslide features and analyze the landscape morphology (Figure 2). Digital image processing was applied to generate shaded relief images derived from DEM and DSM with solar azimuth (sun angle) of $345^{\circ}$, and a solar elevation of $45^{\circ}$. The morphological analysis was based on photointerpretation to identify landslide features by distinctive shape, size, photographic color, tone, texture and pattern of objects (Guzzetti et al., 2012). The identification of the landslide signature in colored digital orthophotos was performed in the evidence of bare soil, bare rock and suppressed vegetation, which were recognized by color, tone and shape. To identify landslide in DEM and DSM shaded relief images, certain textures and patterns were crisscrossed with areas where vegetation was suppressed and the topography changed. The use of shaded relief images has become very common in landslide identification and mapping, especially very high resolution DEM and DSM obtained from LIDAR aerial surveys or by Unmanned aerial systems(UASs), respectively (Ardizzone et al., 2007; Schulz, 2007; Saito et al., 2018).

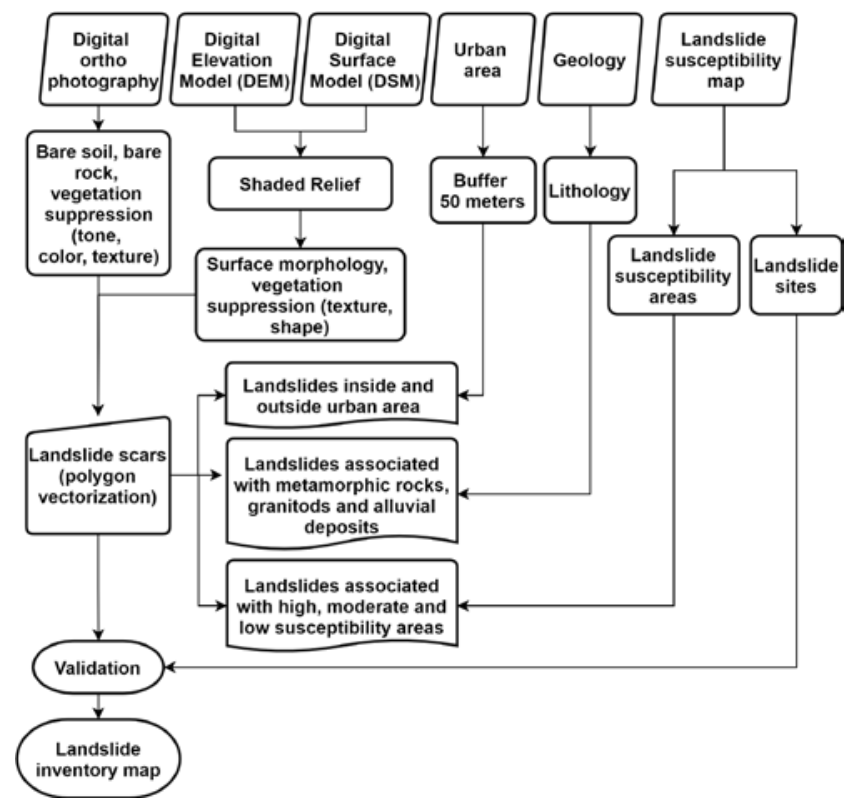

Figure 2. Flow chart shows the methodology.

\subsection{Type of mass movement}

Polygon features were created by tracing the landslide scars. The following attributes were inserted in the landslide database: latitude and longitude, datum, city, state, watershed, landslide type, year. Area and perimeter were calculated for each landslide feature. The landslides were classified according to the type of mass movement: falls, topples, slides, flows and spread (Varnes, 1978; Cruden \& Varnes, 1996; Du et al., 2020; Bordoni et al., 2020). The classification of the type of mass movement was based on visual interpretation of orthophotos, DEM and DSM.

\subsection{Analysis of the geological and landslide susceptibility maps}

The landslide inventory map was overlapped with the Brusque urban area data, in order to identify anthropic-induced mass movements triggered by earthmoving (e.g. cut-and-fills), deforestation, irregular occupation and other activities. Usually, such anthropic interventions occur near the perimeter of the urban area.

Both the 1:100,000-scale geological (CPRM, 2003; Basei et al., 2011) and 1:50,000-scale landslide susceptibility (IPT, 2015) maps were used to analyze the relationship between landslide occurrences and the geological context in landslide-prone areas (Figures 1 and 3). 
The validation of this method was carried out using 33 landslide occurrences observed in the 1:50,000-scale landslide susceptibility map (IPT, 2015).

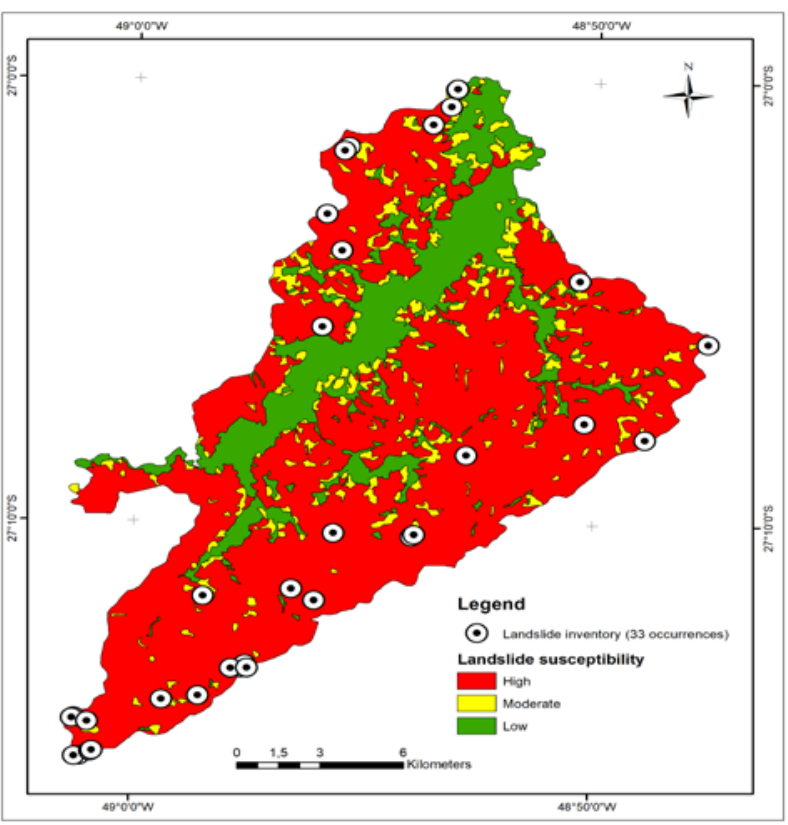

Figure 3. Landslide susceptibility map at 1:50,000 scale, with the location of 33 landslide sites (Modified after CPRM, 2013).

\section{RESULTS AND DISCUSSION}

The results thus obtained showed that digital orthophotos can aid the identification of landslide scars, which are characterized by suppression of vegetation, exposition of bedrock and soil, and traces of mass movement. The shaded relief images revealed details of the morphology of the bedrock and unconsolidated sediments. The landslide inventory included a total of 500 landslides, corresponding to an average density of 1.76 landslides per $\mathrm{km}^{2}$ (Table 1). The total area of landslide occurrences is $0.81 \mathrm{~km}^{2}$, which corresponds to $0.29 \%$ of the study area. The area of largest landslide thus mapped is 0.06 $\mathrm{km}^{2}$; the smallest landslide size is $33 \mathrm{~m}^{2}$ (Figures 4 and 5C).

\begin{tabular}{lc}
\hline & $\begin{array}{c}\text { Landslide } \\
\text { inventory }\end{array}$ \\
\hline Date of inventory (year) & 2010 \\
Scale of aerial photographs & $1: 10,000$ \\
Study area extent $\left(\mathrm{km}^{2}\right)$ & 283.3 \\
Total number of mapped landslides & 500 \\
Total mapped landslide area $\left(\mathrm{km}^{2}\right)$ & 0.81 \\
Percentage of landslide area $(\%)$ & 0.29 \\
Landslide density (number of slides $\left./ \mathrm{km}^{2}\right)$ & 1.76 \\
Smallest mapped landslide $\left(\mathrm{m}^{2}\right)$ & 33 \\
Largest mapped landslide $\left(\mathrm{km}^{2}\right)$ & 0.06 \\
Total of landslides within the urban area $\left(\mathrm{km}^{2}\right)$ & 0.22 \\
Percentage of landslides within the urban $\left.\mathrm{area}^{2} \%\right)$ & 28 \\
Total of landslides outside the urban area $\left(\mathrm{km}^{2}\right)$ & 0.59 \\
Percentage of landslides outside the urban area & 72 \\
(\%) & \\
\hline
\end{tabular}

Table1. Statistics from the landslide inventory for the Brusque region.

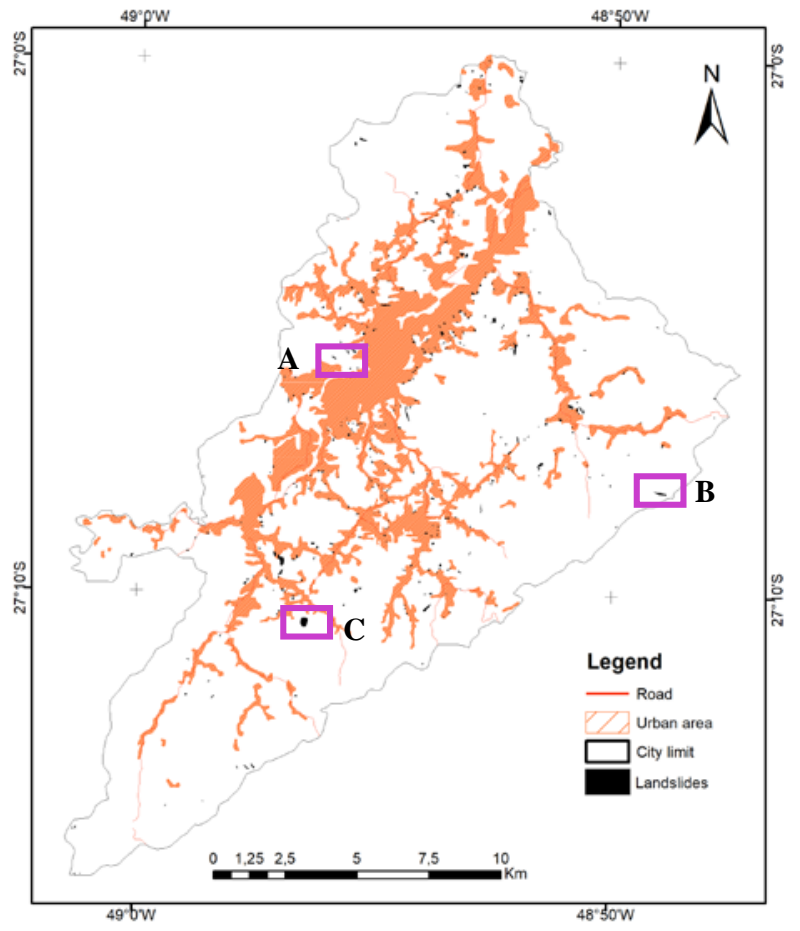

Figure 4. Landslide inventory map for the Brusque city showing the location of 500 landslides identified in remote sensors products acquired in 2010. The purple polygons indicate the location of landslides of the 5A, 5B and 5C figures.
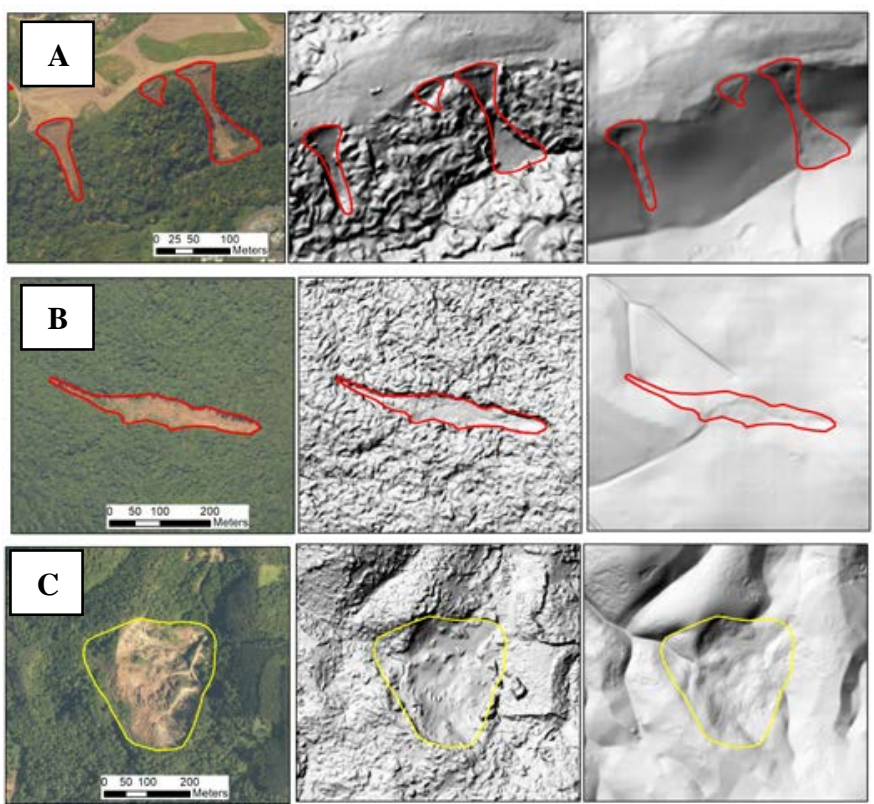

Figure 5. Detail of landslides identified in high spatial resolution aerial photographs and in shaded relief images derived from DSM and DEM.

\subsection{Brusque urban area}

This study revealed that $0.22 \mathrm{~km}^{2}$ (28\%) and $0.59 \mathrm{~km}^{2}$ (72\%) of landslides occur respectively within and outside the perimeter of the urban area of Brusque (Table 1). A buffer zone of $50 \mathrm{~m}$ from the urban perimeter was generated and the result of the analysis showed that $0.35 \mathrm{~km}^{2}$ (43\%) of the landslides occur 
inside the urban perimeter plus the buffer zone and $0.46 \mathrm{~km}^{2}$ (57\%) outside this area. In the buffer zone an increase of $56 \%$ of landslides was observed.

\subsection{Geological context}

The geological context of the landslide occurrences was analyzed, resulting in 277 (55.4\%) landslides related to metapsammite and metapelitic rocks covering an area of about $0.32 \mathrm{~km}^{2} \quad(40 \%) ; 179 \quad(35.8 \%)$ related to granitoids, corresponding to an area of $0.42 \mathrm{~km}^{2}(51.5 \%)$, and $44(8.5 \%)$ landslides related to alluvial deposits corresponding to an area of $0.07 \mathrm{~km}^{2}$ (Table 2). Metamorphic rocks include chlorite biotite sericite schist, muscovite quartz schist, and garnet mica quartz schist, and display penetrative NE-SW foliation that dips from shallow to deep angles towards SE and NW (CPRM, 2003). Granitoid rocks comprise porphyritic biotite monzogranite to syenogranite with magmatic and locally tectonic foliation. The number of landslides related to metamorphic rocks is greater than that related to granitoids, but the area of landslides related to granitoids is greater that related to metasedimentary rocks. A mean landslide size of 2,241 $\mathrm{m}^{2}$ was observed in granitoids, whereas in metamorphic rocks the mean landslide size is $1,116 \mathrm{~m}^{2}$. The lithological and structural characteristics of the metamorphic rocks and granitoids of the study area suggested failure in weak zones, such as foliations, faults and fractures.

\begin{tabular}{|c|c|c|c|c|}
\hline Lithology & MM & PG & $\mathrm{AD}$ & Total \\
\hline Area $\left(\mathrm{km}^{2}\right)$ & 105.8 & 136.7 & 40.8 & 283.3 \\
\hline Percentage in area (\%) & 37.3 & 48.3 & 14.4 & 100 \\
\hline $\begin{array}{l}\text { Area of mapped } \\
\text { landslides }\left(\mathrm{km}^{2}\right)\end{array}$ & 0.32 & 0.42 & 0.07 & 0.81 \\
\hline $\begin{array}{l}\text { Percentage of mapped } \\
\text { landslides (\%) }\end{array}$ & 40 & 51.5 & 8.5 & 100 \\
\hline $\begin{array}{l}\text { Number of mapped } \\
\text { landslide centroids }\end{array}$ & 277 & 179 & 44 & 500 \\
\hline $\begin{array}{l}\text { Mean landslide size } \\
\left(\mathrm{m}^{2}\right)\end{array}$ & 1,116 & 2,241 & 1,148 & \\
\hline
\end{tabular}

Table 2. Area, number of landslides, and correlation with the geological context of Brusque city. MM: Metapelite and metapsammite; PG: Porphyritic granitoids; AD: Alluvial deposits.

\subsection{Landslide susceptibility areas}

Three susceptibility classes were identified in the landslide susceptibility map: high, moderate and low (Figure 2). The high susceptibility class corresponds to $205.3 \mathrm{~km}^{2}$ in area and is characterized by altitudes between 70 and $300 \mathrm{~m}$, slope declivities greater than $25^{\circ}$, and shallow soil cover (Table 3 ). The metamorphic rocks and granitoids are the main lithological units that compose the high susceptibility class. In this class 315 landslides covering $0.51 \mathrm{~km}^{2}$ were observed. The moderate susceptibility class totalizes $24.6 \mathrm{~km}^{2}$ and is characterized by low elevations, ranging from 30 to $100 \mathrm{~m}$, declivities from $10^{\circ}$ to $30^{\circ}$, and a thick soil cover. In this class, advanced erosion has sculptured metamorphic rocks and granitoids. A total of 108 landslides corresponding to $0.14 \mathrm{~km}^{2}$ in area occur in the moderate susceptibility class. The low susceptibility class occupies $53.4 \mathrm{~km}^{2}$ and is characterized by altitudes below $50 \mathrm{~m}$, declivities less than $15^{\circ}$, and alluvial soil. In this class, alluvial deposits predominate, where 77 landslides were identified covering $0.16 \mathrm{~km}^{2}$. The overlapping of maps revealed that $63 \%$,
$17 \%$ and $20 \%$ of landslides occur in high, moderate and low susceptibility areas, respectively. This analysis shows that $80 \%$ of the mapped landslides occur in high and moderate susceptibility areas.

\begin{tabular}{|c|c|c|c|}
\hline Susceptibility & High & Moderate & Low \\
\hline Area $\left(\mathrm{km}^{2}\right)$ & 205.3 & 24.6 & 53.4 \\
\hline Percentage in area (\%) & 72.5 & 8.7 & 18.8 \\
\hline $\begin{array}{l}\text { Area of mapped landslides } \\
\left(\mathrm{km}^{2}\right)\end{array}$ & 0.51 & 0.14 & 0.16 \\
\hline $\begin{array}{l}\text { Occurrence of mapped } \\
\text { landslide (\%) }\end{array}$ & 63 & 17 & 20 \\
\hline
\end{tabular}

Table 3. Classification of landslide susceptibility, areas and numbers of landslides identified in each class.

\subsection{Validation}

The method was validated with 33 landslide sites recorded in the landslide susceptibility map database. Twenty-five landslide sites (76\%) showed good correlation with the landslide susceptibility map. The non-correlation of the remaining landslides with the map is explained by the small size of these landslides and the covering of old landslide scars with vegetation, making their identification in orthophotos difficult.

\section{CONCLUSION}

High spatial resolution remote sensing images, such as orthophotos, DEM and DSM, are useful tools when updating large scale landslide inventory maps, especially when the access to hazard areas is difficult or impossible. This method allowed the identification of landslide scars and the compilation of historical landslide records after the 2008 natural disaster event in Brusque city.

The free access to high spatial resolution orthophotos, DEM and DSM covering the whole State of Santa Catarina, will make the updating of the 2010 landslide inventory possible, with a systematics based on the method presented in this study. The upgrading of the landslide inventory can also be performed using an Unmanned Aerial Vehicles (UAVs), which can acquire high spatial resolution images soon after the natural hazard had occurred.

\section{REFERENCES}

Ardizzone, F., Cardinali, M., Galli, M., Guzzetti, F., Reichenbach, P. 2007. Identification and mapping of recent rainfall-induced landslides using elevation data collected by airborne LiDAR. Natural Hazards and Earth System Sciences 7(6), 637-650. www.nat-hazards-earth-syst-sci.net/7/637/2007/

Basei, M.A.S., Campos Neto, M.C., Castro, N.A., Nutman, A.P., Wemmer, K., Yamamoto, M.T., Hueck, M., Osako, L.S., Siga, O., Passarelli, C.R. 2011. Tectonic evolution of the Brusque Group, Dom Feliciano belt, Santa Catarina, Southern Brazil. Journal of South American Earth Sciences, 32: 324-350. doi.org/10.1016/j.jsames.2011.03.016.

Bordoni, M., Galanti, Y., Bartelletti, C., Persichillo, M.G., Barsanti, M., Giannecchini, R., Avanzi, G.D., Cevasco, A., Brandolini, P., Galve, J.P., Meisina, C. 2020. The influence of the inventory on the determination of the rainfall-induced shallow landslides susceptibility using generalized additive models. Catena, 193: 1-17. doi.org/10.1016/j.catena.2020.104630. 
Bonham-Carter, G.F. 1994. Geographic Informations Systems for Geoscientists, Modeling with GIS. New York, Pergamon.

CPRM - Geological Survey of Brazil. 2003. Geologia, tectônica e recursos minerais do Brasil: texto, mapas \& SIG. Org. Bizzi, L.A., Schobbenahus, C., Vidotti, R.M., Gonçalves, J.H. Brasília, 692p.

Cruden, D.M., Varnes, D.J. 1996. Landslide types and processes. In Landslides: Investigation and Mitigation, Turner, A.K. and Schuster, R.L.(eds). Transportation Research Board Special Report 247, US National Research Council, Washington, DC, Chapter 3, pp. 36-75

Du, J., Glade, T., Woldai, T., Chai, B., Zeng, B. 2020. Landslide susceptibility assessment based on an incomplete landslide inventory in the Jilong Valley, Tibet, Chinese Himalayas. Engineering Geology, 270: 1-25. doi.org/10.1016/jenggeo.2020.105572.

Guzzetti, F., Cardinali, M., Reichenbach, P., Carrara, A. 2000. Comparing landslide maps: a case study in the upper Tiber River Basin, Central Italy. Environmental Management, 25 (3), 247-363. doi.org/10.1007/s002679910020.

Guzzetti, F., Mondini, A.C., Cardinali, M., Fiorucci, F., Santangelo, M., Chang, K.T. 2012. Landslide inventory maps: New tools for an old problem. Earth Science Reviews, 112:4266. doi.org/10.1016/j.earscirev.2012.02.001.

IPT - Instituto de Pesquisas Tecnológicas. 2015. Carta de suscetibilidade a movimentos gravitacionais de massa e inundações: Município de Brusque - SC. Scale 1:50,000. rigeo.cprm.gov.br/jspui/handle/doc/15117.

Longley, P.A., Goodchild, M.F., Maguire, D.J., Rhind, D.W. 2013. Sistemas e Ciência da Informação Geográfica. $3^{\mathrm{a}}$ ed. Porto Alegre, Bookman.

Malamud, B.D., Turcotte, D.L., Guzzetti, F., Reichenbach, P. 2004. Landslide inventories and their statistical properties. Earth and Planetary Science Letters, 229, 45-59.

Mondini, A.C., Viero, A., Cavalli, M., Marchi, L., Herrera, G., Guzzetti, F. 2014. Comparison of event landslide inventories: the Pogliaschina catchment test case, Italy. Natural Hazards and Earth System Sciences, 14, 1749-1759. doi.org/10.5194/nhess-14-1749-2014.

Reichenbach, P., Rossi, M., Malamud, B.D., Mihir, M., Guzzetti, F. 2018. A review of statistically-based landslide susceptibility models. Earth Science Reviews, 180: 60-91. doi.org/10.1016/j.earscirev.2018.03.001.

Saito, H., Uchiyama, S., Hayakawa, Y.S., Obanawa, H.2018. Landslides triggered by an earthquake and heavy rainfalls at Aso volcano, Japan, detected by UAS and SfM-MVS photogrammetry. Progress in Earth and Planetary Science, 5:15. doi.org/10.1186/s40645-018-0169-6

SDS - Secretaria de Estado do Desenvolvimento Econômico Sustentável, 2010. Download of orthophotos, Digital Surface Model and Digital Elevation Model. sigsc.sds.sc.gov.br. (5 January 2020)
Schulz, W.H. 2007. Landslide susceptibility revealed by LIDAR imagery and historical records, Seattle, Washington. $\begin{array}{llll}\text { Engineering Geology, 67-87. } & \text { 89, }\end{array}$ doi.org/10.1016/j.enggeo.2006.09.019.

Varnes, D.J. 1978. Slope movement types and processes. In: Schuster, R.L. and Krizek, R.J., eds., Landslides - Analysis and control: National Research Council, Washington, D.C., Transportation Research Board, Special Report 176, p.11-33. 